\title{
PROSPEK PENGEMBANGAN PALA RAKYAT DI PROVINSI LAMPUNG
}

\author{
(Prospect Development of Nutmeg in Lampung Province)
}

Fitri Yuni Lestari, Raden Hanung Ismono, Fembriarti Erry Prasmatiwi

Jurusan Agribisnis, Fakultas Pertanian, Universitas Lampung, Jl. Prof. Dr. Soemantri Brodjonegoro No. 1

Bandar Lampung 35145, Telp. 082179960186,e-mail: fyl.lestari@gmail.com

\begin{abstract}
The research aimed to analyze financial feasibility and development prospect of nutmeg farming in Lampung Province. This research was conducted in Gisting Subdistrict of Tanggamus Regency in which data was collected in September 2017 until October 2017 by survey method. This research used primary and secondary data. Primary data was used to answer financial feasibility analyze purpose and obtained by interview technique using questionnaires. Secondary data in the past seven to night years was used to answer the purpose of prospect development of nutmeg farming. The samples size of this research was 30 nutmeg farmers using simple random sampling. The data was analyzed by financial feasibility and time series linier with ARIMA model. The results of the study showed that the nutmeg farming was feasible, and development prospect of nutmeg farming based on production and nutmeg seeds export had a good potential for the future.
\end{abstract}

Key words: ARIMA, development, financial, nutmeg, prospect

\section{PENDAHULUAN}

Tanaman pala merupakan tanaman perkebunan yang memiliki potensi sebagai komoditas ekspor dan saat ini terus dikembangkan di Indonesia. Provinsi Lampung telah mengembangkan usahatani pala dengan perkembangan luas lahan pala yang cenderung meningkat dengan rata-rata sebesar 34,89\% per tahunnya (Dinas Perkebunan Provinsi Lampung 2016). Sentra penghasil pala di Provinsi Lampung yakni di Kecamatan Gisting Kabupaten Tanggamus dengan luas lahan usahatani pala sebesar 789 hektar dan memiliki produktivitas pala sebesar $680 \mathrm{~kg} / \mathrm{ha}$ (Dinas Perkebunan Provinsi Lampung 2015).

Mayoritas budidaya tanaman pala dilakukan secara tumpangsari dengan tanaman lain seperti kakao, pisang, dan kelapa. Hal tersebut dilakukan karena pertimbangan petani bahwa masa tunggu tanaman pala hingga menghasilkan yang cukup lama yakni 5 hingga 7 tahun dari awal penanaman (Hatta 1993). Menurut (Borolla 2014), kendala pengembangan usahatani pala yang dilakukan yakni masih terbatasnya data dan informasi mengenai ketepatan kelayakan dalam usaha yang dapat dijadikan sebagai acuan dalam pemanfaatan sumber daya optimal.

Hasil produksi pala yakni berupa biji pala dan fuli pala yang dijual dalam bentuk kering. Harga jual biji pala kering sebesar Rp35.000,00/kg dan fuli kering sebesar Rp110.000,00/kg. Harga tersebut merupakan harga terendah yang pernah diterima petani. Rendahnya harga jual hasil produksi pala disebabkan faktor cuaca yang mempengaruhi penangan pasca panen pala. Penanganan pasca panen pala yang masih menggunakan sinar matahari memerlukan kondisi cuaca yang baik untuk pengeringan biji pala dan fuli pala.

Tanaman pala merupakan komoditas rempah utama Indonesia selain lada, cengkeh, dan kayu manis dengan nilai ekspor terbesar kedua setelah lada (BPS 2014). Hasil keseluruhan produksi pala dapat dimanfaatkan dan memiliki nilai ekonomi yang tinggi. Provinsi Lampung mulai melakukan ekspor biji pala pada tahun 2011 dengan volume ekspor sebesar 26 ton, dan pada tahun 2017 sebesar 28,10 ton (Dinas Perdagangan Provinsi Lampung 2017).

Penanganan pasca panen pala yang masih tradisional berpengaruh terhadap mutu hasil produksi pala. Perkembangan ekspor biji pala yang fluktuatif di Provinsi Lampung pada tahun 2011 hingga tahun 2017 menunjukkan adanya peluang perdagangan komoditas pala di pasar internasional. Hal tersebut yang melatarbelakangi untuk dilaksanakannya penelitian lebih mendalam mengenai prospek pengembangan usahatani pala rakyat di Provinsi Lampung. Berdasarkan uraian tersebut, penelitian ini bertujuan menganalisis kelayakan finansial dan sensitivitas usahatani pala, 
serta menganalisis prospek pengembangan usahatani pala rakyat di Provinsi Lampung.

\section{METODE PENELITIAN}

Penelitian dilaksanakan di Kecamatan Gisting yang merupakan sentra penghasil pala di Kabupaten Tanggamus. Lokasi penelitian dipilih secara sengaja (purposive) dengan pertimbangan bahwa kecamatan tersebut merupakan sentra penghasil pala di Provinsi Lampung.

Penelitian ini menggunakan metode survei. Pengambilan data penelitian dilaksanakan pada bulan September hingga Oktober 2017 di Desa Campang Raya dan Desa Gisting Atas Kecamatan Gisting. Metode pengambilan sampel yang digunakan menggunakan sistem acak sederhana (simple random sampling). Jumlah sampel dalam penelitian ini adalah 30 responden petani pala. Penentuan sampel di masing-masing desa/pekon ditentukan menggunakan alokasi proporsional dengan memperoleh jumlah responden petani pala sebanyak 13 responden berasal dari Desa Gisting Atas dan sebanyak 17 responden berasal Desa Campang.

Jenis data yang digunakan dalam penelitian adalah data primer dan data sekunder. Data primer diperoleh melalui teknik wawancara menggunakan kuesioner. Data sekunder digunakan untuk data ekspor biji pala dan produksi pala di Provinsi Lampung yang diperoleh dari Dinas Perkebunan Provinsi Lampung dan Dinas Perdagangan Provinsi Lampung dalam kurun waktu 10 tahun terakhir.

Metode analisis data yang digunakan dalam penelitian ini menggunakan dua cara yaitu metode analisis kualitatif dan analisis kuantitatif. Analisis kuantitatif digunakan untuk mengetahui analisis kelayakan finansial (Net Present Value, Net B/C, Gross B/C, Internal Rate of Return, dan Payback Periode), analisis sensitivitas, dan analisis prospek pengembangan usahatani pala. Analisis kualitatif digunakan untuk menjelaskan hasil yang diperoleh dari analisis kuantitatif yang telah dilakukan.

Nilai suku bunga yang digunakan yakni 9\% berdasarkan suku bunga pinjaman Kredit Usaha Rakyat (KUR) retail Bank BRI. Hal tersebut dikarenakan lembaga keuangan tersebut mayoritas digunakan oleh petani pala. Umur proyek yang digunakan dalam penelitian ini yakni 25 tahun. Menurut Kadariah (2001) apabila suatu proyek memiliki umur ekonomis diatas 25 tahun, maka dapat dianggap hanya sampai umur 25 tahun, dikarenakan jika manfaat proyek setelah umur 25 tahun di discount kan menggunakan suku bunga diskonto di atas 10 persen akan menghasilkan penerimaan sekarang (present value) yang kecil.

Analisis kelayakan finansial merupakan analisis yang bertujuan untuk menilai apakah suatu kegiatan investasi (usaha) yang dijalankan tersebut layak atau tidak untuk dijalankan. Menurut Kadariah (2001), terdapat beberapa kriteria investasi yang digunakan dalam analisis kelayakan finansial, yaitu :

\section{Net Present Value (NPV)}

$$
\mathrm{NPV}=\sum_{\mathrm{t}-1}^{\mathrm{n}} \frac{\mathrm{Bt}-\mathrm{Ct}}{(1+\mathrm{t})^{\mathrm{t}}}
$$

Keterangan :

$\mathrm{Bt}=$ Manfaat dari proyek pada tahun ke $-\mathrm{t}$

$\mathrm{Ct}=$ Biaya $($ cost $)$ pada tahun ke-t

$\mathrm{n}=$ Umur proyek (25 tahun)

$\mathrm{i}=$ Tingkat suku bunga $9 \%$

Kriteria pada pengukuran ini adalah :

1. Jika NPV (> 0) maka investasi layak dilaksanakan

2. Jika NPV $(<0)$ maka investasi tidak layak untuk dilaksanakan

\section{Gross Benefit Cost Rasio (Gross B/C)}

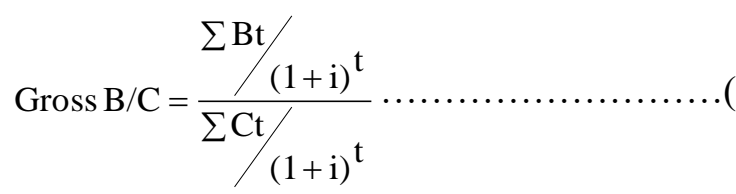

Keterangan :

$\mathrm{Bt}=$ Manfaat (benefit) pada tahun ke-i

$\mathrm{Ct}=$ Biaya $($ cost $)$ pada tahun ke-i

Kriteria pada pengukuran ini adalah :

1. Gross $\mathrm{B} / \mathrm{C}>1$, maka kegiatan usaha layak untuk dilaksanakan.

2. Gross $B / C<1$, maka kegiatan usaha tidak layak untuk dilaksanakan

3. Gross $\mathrm{B} / \mathrm{C}=0$, maka kegiatan usaha dalam keadaan break event point.

\section{Net Benefit Cost Rasio (Net B/C)}

Net B/C Ratio $=\frac{\sum_{\mathrm{PV} \text { net } \mathrm{Bt} \text { positif }}}{\sum_{\mathrm{PV} \text { net } \mathrm{Bt} \text { negatif }}}$ 
Keterangan :

$\mathrm{Bt}=$ Manfaat (benefit) pada tahun ke-i

Keterangan :

1. Jika $(\mathrm{NetB} / \mathrm{C}>1)$, maka proyek layak dilaksanakan.

2. Jika (Net $\mathrm{B} / \mathrm{C}<1)$, maka proyek tersebut tidak layak untuk dilaksanakan

\section{Internal Rate of Return (IRR)}

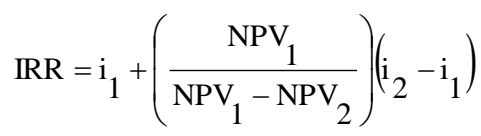

Keterangan:

NPV $1=$ NPV bernilai positif

NPV 2 = NPV bernilai negatif

$\mathrm{i}_{1} \quad=$ Tingkat suku bunga saat NPV $(+)$

$\mathrm{i}_{2} \quad=$ Tingkat suku bunga saat NPV (-)

\section{Payback Periode (PP)}

$$
\mathrm{PP}=\mathrm{n}+\frac{\mathrm{a}-\mathrm{b}}{\mathrm{c}-\mathrm{b}} \times 1 \text { tahun }
$$

Keterangan:

$\mathrm{n}=$ Tahun terakhir jumlah arus kas yang belum bisa menutupi investasi awal

$\mathrm{a}=$ Investasi mula-mula

$\mathrm{b}=$ Arus kas kumulatif tahun ke-n

$\mathrm{c}=$ Arus kas kumulatif tahun ke $\mathrm{n}+1$

\section{Analisis Sensitivitas}

Analisis sensitivitas digunakan untuk menghitung kepekaan dari analisis Net Present Value (NPV), Net B/C Rasio, Gross B/C Rasio, Internal Rate of Return (IRR), Payback Period (PP), terhadap perubahan yang terjadi di masa mendatang, seperti peningkatan biaya produksi sebesar 4,45 \% dan penurunan sebesar $25 \%$. Peningkatan biaya produksi didasarkan pada tingkat inflasi tertinggi pada tahun 2016 yakni sebesar $4,45 \%$, penurunan produksi $25 \%$ disebabkan oleh penyakit busuk buah pala dengan rata-rata penurunan produksi sebesar $25 \%$.

Secara matematis, menurut Gittinger (1993) analisis laju kepekaan dirumus sebagai berikut :

$$
\text { Laju kepekaan }=\frac{\frac{X i-X o}{X}}{\frac{Y i-Y o}{Y}} \text {. }
$$

Keterangan :

$$
\begin{aligned}
\mathrm{Xi}= & \text { Gross } \mathrm{B} / \mathrm{C} / \text { Net } \mathrm{B} / \mathrm{C} / \mathrm{NPV} \text { IRR/PP setelah } \\
\text { perubahan } & \\
\mathrm{Xo}= & \begin{array}{l}
\text { Gross } \mathrm{B} / \mathrm{C} / \text { Net } \mathrm{B} / \mathrm{C} / \mathrm{NPV} \text { IRR/PP sebelum } \\
\text { perubahan }
\end{array} \\
\mathrm{X}= & \text { Rata-rata perubahan Gross } \mathrm{B} / \mathrm{C} / \text { Net } \mathrm{B} / \mathrm{C} / \\
& \mathrm{NPV} \text { IRR/PP } \\
\mathrm{Yi}= & \text { Biaya produksi/produksi setelah perubahan } \\
\mathrm{Yo}= & \text { Biaya produksi/produksi sebelum } \\
& \text { perubahan } \\
\mathrm{Y}= & \begin{array}{l}
\text { Rata-rata perubahan } \\
\text { produksi/produksi }
\end{array}
\end{aligned}
$$

\section{Analisis Prospek Pengembangan Pala Rakyat di Provinsi Lampung}

Proses peramalan menggunakan metode analisis time series model ARIMA (Autoregressive Integrated Moving Average). Metode ini terdiri dari tiga tahap yaitu, tahap pertama yakni identifikasi awal yang meliputi identifikasi data pada uji root test dengan melihat nilai Levin, Lin \& Chu $t^{*}$. Jika nilai Levin, Lin \& Chu $t^{*}>\alpha 5 \%$ maka data yang identifikasi belum stasioner. Oleh sebab itu, perlu dilakukan tahap selanjutnya yakni proses differencing. Pada tahap pertama untuk data ekspor biji pala dan produksi pala di Provinsi Lampung menunjukkan tingkat stasioner data pada proses $1^{\mathrm{st}}$ differencing.

Tahap ke dua yakni penaksiran parameter (estimasi), dengan melihat hasil estimasi parameter maka dapat ditentukan apakah dugaan model sementara tersebut sesuai atau tidak untuk peramalan. Penaksiran parameter yang dilakukan untuk produksi pala dan ekspor biji pala di Provinsi Lampung masing-masing menghasilkan empat model. Pemilihan model terbaik dilihat dari nilai Schwars Criterion dan nilai Akaike Info Criterion (AIC) yang kecil, nilai Sum Squared Resid (SSE) dan nilai Adjusted $R$ Squared yang besar. Keriteria-keriteria tersebut digunakan untuk membandingkan masing-masing model penaksiran parameter (estimasi), sehingga memperoleh model terbaik.

Tahap ke tiga yakni peramalan (forcasting) yang dilakukan selama 10 tahun ke depan. Setelah didapatkan model terbaik dan persamaan dari proses penaksiran parameter (estimasi), maka langkah selanjutnya adalah melakukan peramalan dengan memasukkan nilai-nilai dalam persamaan yang telah diperoleh. Model terbaik yang digunakan untuk peramalan (forcasting) produksi pala di Provinsi Lampung yakni $(1,1,5)$ dengan persamaan $\mathrm{Yt}=1,153+0,380$ ut-1 $-0,999$ ut-5. 
Model terbaik yang digunakan untuk peramalan ekspor biji pala di Provinsi Lampung yakni $(0,1,4)$ dengan persamaan $\mathrm{Yt}=8,834-0,999 \mathrm{ut}-4+$ et.

\section{HASIL DAN PEMBAHASAN}

\section{Keadaan Umum Responden}

Sebagian besar petani pala di Kecamatan Gisting berada pada usia produktif, yakni pada umur 44-57 tahun $(40,00 \%)$. Tingkat pendidikan petani pala tergolong rendah yaitu hanya pada tingkatan SD $(43,33 \%)$. Petani pala memiliki rata-rata luas lahan seluas 0,59 hektar. Mayoritas petani pala memiliki pekerjaan sampingan (63,33\%). Pengalaman usahatani pala yang di miliki petani rata-rata selama 12,8 tahun. Jarak tanam yang digunakan $7 \mathrm{~m} \times 7 \mathrm{~m}(66,67 \%)$. Jumlah pohon pala yang ditanam petani sebanyak 213 pohon/ha. Umur tanaman pala yang ditanam petani rata-rata berusia 15,5 tahun. Sebesar $75,58 \%$ petani menanam tanaman pala dalam satu luasan lahan yang dimiliki petani, sedangkan sisanya sebesar $24,51 \%$ ditanami tanaman tumpangsari yang dimanfaatkan untuk menambah pendapatan petani sebelum masa panen pala. Jenis tanaman tumpangsari yang diusahakan yaitu kakao, pisang, dan kelapa.

\section{Biaya Investasi}

Tanaman pala mulai berbunga pada usia empat tahun dan dapat dipanen pada umur lima tahun. Biaya usahatani pala yang dikeluarkan pada masa Tanaman Belum Menghasilkan (TBM) dianggap sebagai biaya investasi yakni pada tahun pertama hingga tahun ke empat. Biaya investasi pada masa TBM meliputi biaya bibit, biaya peralatan, biaya pupuk, biaya pestisida, biaya tenaga kerja, dan pajak. Lahan yang dimiliki keseluruhan responden petani pala yakni lahan milik sendiri

Bibit pala yang diperoleh petani responden adalah bibit lokal dengan harga rata-rata sebesar Rp6.600,00/batang. Rata-rata dalam 1 hektar lahan pala ditanami sebanyak 213 bibit pala, sehingga biaya bibit yang dikeluarkan sebesar Rp976.500,00/ha. Peralatan yang digunakan pada usahatani pala meliputi cangkul, golok, arit, sprayer, dan gancu. Rata-rata biaya peralatan usahatani pala sebesar Rp443.877,00. Biaya pupuk pada masa TBM meliputi penggunaan pupuk kandang, phonska, urea, dan dolomit. Ratarata biaya pupuk yang dikeluarkan pada masa TBM sebesar Rp966.060,00/ha dan besar biaya pestisida untuk pengendalian hama penyakit tanaman pala yang dikeluarkan petani sebesar Rp421.211,00/ha.

Biaya tenaga kerja yang dikeluarkan pada tahun pertama yakni sebesar Rp2.725.028,00/ha yang digunakan untuk pengolahan lahan, penanaman bibit pala, dan pemeliharaan (penyiangan, penyulaman, pemupukan, dan pengendalian HPT). Biaya tenaga kerja yang dikeluarkan pada tahun ke 2 hingga tahun ke 4 yakni rata-rata sebesar Rp1.617.944,00/ha. Biaya pajak yang dikeluarkan petani pala pada masa TBM sebesar Rp31.017,00/ha/tahun. Total biaya investasi pada masa TBM yakni sebesar Rp10.606.44,00.

\section{Biaya Operasional}

Biaya operasional adalah biaya yang habis dipakai dalam satu kali produksi pada masa Tanaman Menghasilkan (TM). Biaya operasional yakni pada tahun ke 5 hingga tahun ke 25 yang dapat dilihat pada Tabel 1. Biaya operasional usahatani pala meliputi biaya pupuk, pestisida, tenaga kerja, biaya pengolahan pala, dan pajak. Pupuk yang digunakan pada masa TM adalah pupuk phonska yang diberikan hanya dua tahun sekali setelah panen pertama dengan biaya pupuk sebesar Rp360.278,00/ha. Pemberiaan pestisida setelah masa TM rata-rata diberikan hingga usia tanaman pala mencapai usia 10 tahun dengan biaya yang dikeluarkan sebesar Rp225.978,00/ha.

Total biaya tenaga kerja usahatani pala pada masa TM adalah Rp3.232.225,00/ha/tahun. Tenaga kerja yang digunakan untuk pemeliharaan, panen dan pasca panen. Biaya pasca panen dimasukkan sebagai biaya pengolahan pala menjadi biji kering dan fuli kering dengan rata-rata biaya pengolahan sebesar Rp2.181.744,00. Jumlah hari tenaga kerja akan menyesuaikan dengan jumlah produksi yang dihasilkan. Biaya tenaga kerja yang dikeluarkan pada masa tanaman menghasilkan dipengaruhi oleh hasil panen yang diperoleh.

Selain itu, petani juga melakukan usahatani lain dengan menanam tanaman lain sebagai tanaman tumpangsari seperti pisang, kakao, dan kelapa. Hal tersebut dikarenakan masa tunggu tanaman pala hingga menghasilkan yang cukup lama yakni 5 hingga 7 tahun. Selama masa tunggu tanaman pala hingga panen, petani masih memperoleh penerimaan dari tanaman tumpangsari yang diusahakan. Biaya tanaman tumpangsari yang dikeluarkan oleh petani yakni rata-rata sebesar Rp532.444,00. 
Tabel 1. Biaya-biaya usahatani pala per hektar per tahun di Kecamatan Gisting

\begin{tabular}{cccrc}
\hline \multicolumn{5}{c}{ Biaya-biaya $(\mathrm{Rp})$} \\
\hline Thn & $\begin{array}{c}\text { Pupuk } \\
\text { Pestisida }\end{array}$ & \multicolumn{1}{c}{ TK } & $\begin{array}{c}\text { Biaya } \\
\text { lain-lain }\end{array}$ & \multicolumn{1}{c}{ Total } \\
& Biaya \\
\hline 1 & 377.561 & 2.725 .028 & 1.983 .848 & 5.086 .427 \\
2 & 314.683 & 1.617 .944 & 563.461 & 2.496 .089 \\
3 & 306.265 & 1.617 .944 & 568.141 & 2.492 .341 \\
4 & 324.367 & 1.617 .944 & 719.055 & 2.661 .366 \\
5 & 586.256 & 5.413 .969 & 745.974 & 6.746 .200 \\
6 & 225.978 & 5.413 .969 & 563.461 & 6.203 .408 \\
7 & 225.978 & 5.413 .969 & 829.504 & 6.469 .452 \\
8 & 586.256 & 5.413 .969 & 563.461 & 6.563 .686 \\
9 & 225.978 & 5.413 .969 & 745.974 & 6.385 .922 \\
10 & 225.978 & 5.413 .969 & 719.055 & 6.359 .002 \\
11 & 360.278 & 5.413 .969 & 568.141 & 6.342 .388 \\
12 & - & 5.413 .969 & 563.461 & 5.977 .430 \\
13 & - & 5.413 .969 & 1.007 .338 & 6.421 .307 \\
14 & 360.278 & 5.413 .969 & 563.461 & 6.337 .708 \\
15 & - & 5.413 .969 & 568.141 & 5.982 .110 \\
16 & - & 5.413 .969 & 719.055 & 6.133 .025 \\
17 & 360.278 & 5.413 .969 & 745.974 & 6.520 .222 \\
18 & - & 5.413 .969 & 563.461 & 5.977 .430 \\
19 & - & 5.413 .969 & 829.504 & 6.243 .474 \\
20 & 360.278 & 5.413 .969 & 563.461 & 6.337 .708 \\
21 & - & 5.413 .969 & 745.974 & 6.159 .944 \\
22 & - & 5.413 .969 & 719.055 & 6.133 .025 \\
23 & 360.278 & 5.413 .969 & 568.141 & 6.337 .708 \\
24 & - & 5.413 .969 & 563.461 & 5.977 .430 \\
25 & - & 5.413 .969 & 1.007 .338 & 6.421 .307 \\
\hline & & & &
\end{tabular}

\section{Produksi dan Penerimaan}

Tanaman pala mulai menghasilkan pada umur lima tahun. Pada Tabel 2 dapat diketahui bahwa penerimaan pada tahun pertama hingga ke empat berasal dari tanaman tumpangsari seperti pisang, kelapa, dan kakao. Kemudian pada tahun ke lima hingga tahun ke 25 penerimaan responden petani pala yang dijumlahkan dengan penerimaan tumpangsari.

Produksi pala yang dijual secara keseluruhan berupa biji pala kering dan fuli pala kering. Penyusutan biji dan fuli pala yakni sebesar $10 \%$ untuk susut biji pala dan $8 \%-10 \%$ untuk susut fuli pala. Harga biji pala kering dan fuli kering di tingkat petani pada tahun 2017 cukup rendah yang berpengaruh terhadap penerimaan petani pala. Penerimaan petani merupakan hasil kali dari produksi pala dan harga jual pala berupa biji pala dan fuli pala kering. Produksi dan penerimaan yang diperoleh petani pala sangat penting bagi pendapatan usahatani rumah tangga petani.
Tabel 2. Penerimaan usahatani pala dan tanaman tumpangsarinya

\begin{tabular}{|c|c|c|c|c|}
\hline \multirow[b]{2}{*}{ Thn } & \multicolumn{2}{|c|}{ Produksi $(\mathrm{Kg})$} & \multirow{2}{*}{$\begin{array}{l}\text { Nilai Tan. } \\
\text { Tumpangsari } \\
\text { (Rp) }\end{array}$} & \multirow{2}{*}{$\begin{array}{l}\text { Nilai Total } \\
\text { Usahatani } \\
\text { pala (Rp) }\end{array}$} \\
\hline & $\begin{array}{l}\text { Biji } \\
\text { Pala }\end{array}$ & $\begin{array}{l}\text { Fuli } \\
\text { Pala }\end{array}$ & & \\
\hline 1 & - & - & 307.000 & 307.000 \\
\hline 2 & - & - & 307.000 & 307.000 \\
\hline 3 & - & - & 307.000 & 307.000 \\
\hline 4 & - & - & 2.872 .540 & 2.872 .540 \\
\hline 5 & 52 & 5 & 2.872 .540 & 5.277 .317 \\
\hline 6 & 99 & 10 & 2.872 .540 & 7.428 .584 \\
\hline 7 & 145 & 15 & 2.872 .540 & 9.552 .762 \\
\hline 8 & 135 & 14 & 2.872 .540 & 9.102 .984 \\
\hline 9 & 104 & 10 & 2.872 .540 & 7.671 .873 \\
\hline 10 & 147 & 15 & 2.872 .540 & 9.649 .873 \\
\hline 11 & 179 & 18 & 2.872 .540 & 11.121 .873 \\
\hline 12 & 216 & 22 & 2.872 .540 & 12.808 .540 \\
\hline 13 & 197 & 20 & 2.872 .540 & 11.934 .540 \\
\hline 14 & 228 & 23 & 2.872 .540 & 13.345 .206 \\
\hline 15 & 227 & 23 & 2.872 .540 & 13.299 .206 \\
\hline 16 & 192 & 19 & 2.872 .540 & 11.704 .540 \\
\hline 17 & 173 & 17 & 2.872 .540 & 10.821 .340 \\
\hline 18 & 101 & 10 & 2.872 .540 & 7.497 .073 \\
\hline 19 & 78 & 8 & 2.872 .540 & 6.445 .206 \\
\hline 20 & 126 & 13 & 2.872 .540 & 8.683 .873 \\
\hline 21 & 150 & 15 & 2.872 .540 & 9.771 .549 \\
\hline 22 & 150 & 15 & 2.872 .540 & 9.771 .549 \\
\hline 23 & 150 & 15 & 2.872 .540 & 9.771 .549 \\
\hline 24 & 150 & 15 & 2.872 .540 & 9.771 .549 \\
\hline 25 & 150 & 15 & 2.872 .540 & 9.771 .549 \\
\hline 25 & 150 & 15 & 2.872 .540 & 9.771 .549 \\
\hline \multicolumn{5}{|c|}{ Keterangan: } \\
\hline & & & $.000,00 / \mathrm{Kg}$ & \\
\hline Harga & & & $000000 / \mathrm{K}_{\sigma}$ & \\
\hline
\end{tabular}

\section{Analisis Kelayakan Finansial Usahatani Pala}

Analisis kelayakan finansial dilakukan untuk melihat apakah usahatani pala menguntungkan dan layak dikembangkan pada masa mendatang. Hasil perhitungan analisis kelayakan finansial dapat dilihat pada Tabel 3.

Perhitungan nilai Net Present Value pada usahatani pala menghasilkan nilai NPV usahataninya sebesar Rp72.345.512,00. Berdasarkan nilai tersebut, diketahui bahwa usahatani pala layak dan menguntungkan untuk diusahakan karena nilai NPV yang diperoleh lebih besar dari 0 (NPV >0).

Nilai Gross $B / C$ pada usahatani pala yang diperoleh sebesar 1,45. Nilai Gross B/C 1,45 menunjukkan bahwa setiap Rp1,00 biaya yang dikeluarkan menghasilkan penerimaan sebesar Rp1,45. Nilai tersebut lebih dari 1 yang berarti bahwa usahatani pala di Kecamatan Gisting Kabupaten Tanggamus menguntungkan dan layak untuk diteruskan. 
Tabel 3. Hasil analisis kelayakan finansial usahatani pala di Kecamatan Gisting

\begin{tabular}{lrc}
\hline \multirow{2}{*}{ Kriteria } & \multicolumn{2}{c}{ Usahatani pala } \\
\cline { 2 - 3 } & \multicolumn{1}{c}{ Hasil } & Ket \\
\hline Net Present Value (Rp) & 72.345 .512 & Layak \\
IRR $(\%)$ & $18,66 \%$ & Layak \\
Gross B/C & 1,45 & Layak \\
Net B/C & 2,46 & Layak \\
Payback Periode (Tahun) & 4,24 & Layak \\
\hline
\end{tabular}

Usahatani pala dinyatakan layak apabilai nilai IRR yang diperoleh lebih besar dari tingkat suku bunga yang berlaku saat ini. Tingkat suku bunga yang digunakan dalam penelitian ini sebesar $9 \%$. Nilai IRR yang diperoleh untuk usahatani pala yakni sebesar $18,66 \%$, berarti usahatani pala yang diusahakan layak dan menguntungkan untuk dikembangkan. Hal tersebut dikarenakan nilai IRR yang diperoleh lebih besar dibandingkan dengan tingkat suku bunga yang berlaku saat ini (nilai IRR yang diperoleh $>9 \%$ ).

Hasil perhitungan $\mathrm{Net} B / C$ yang diperoleh sebesar 2,46. Hal tersebut berarti bahwa setiap Rp1,00 biaya bersih yang telah dikeluarkan pada usahatani pala akan menghasilkan penerimaan bersih sebesar Rp2,46. Berdasarkan hal tersebut usahatani pala layak dan menguntungkan untuk diusakan karena nilai $\mathrm{Net} B / C$ lebih dari 1 .

Berdasarkan hasil perhitungan diperoleh Payback Period (PP) usahatani pala adalah sebesar 4,24. Hal ini berarti, masa pengembalian investasi pada usahatani pala adalah 4 tahun 2 bulan 26 hari. Perhitungan yang diperoleh tersebut menunjukkan bahwa masa pengembalian modal atau investasi lebih pendek dibandingkan dengan umur ekonomis usaha yang dilakukan, yakni selama 25 tahun. Hasil penelitian ini sejalan dengan penelitian Astanu, Ismono, dan Rosanti (2013) yakni analisis kelayakan finansial pala intensif yang menyatakan bahwa usahatani pala intensif layak dan menguntungkan untuk diusahakan yang dilihat dari ke lima kriteria kelayakan tersebut.

\section{Analisis Sensitivitas}

Selain menghitung analisis finansial, penelitian ini juga menghitung analisis sensitivitas pada usahatani pala tumpangsari. Analisis sensitivitas bertujuan untuk mengetahui apa yang akan terjadi dengan hasil analisis investasi jika terdapat perubahan-perubahan pada perhitungan biaya dan penerimaan.
Tabel 4. Hasil analisis sensitivitas usahatani pala di Kecamatan Gisting

\begin{tabular}{lrrrr}
\hline \multicolumn{1}{c}{ Perubahan } & $\begin{array}{c}\text { Sebelum } \\
\text { Perubahan }\end{array}$ & $\begin{array}{c}\text { Sesudah } \\
\text { Perubahan }\end{array}$ & LK & Ket \\
\hline \multicolumn{2}{c}{ Biaya Produksi naik $4,45 \%$} \\
NPV (Rp) & 72.345 .512 & 59.301 .288 & 0,05 & TS \\
Gross B/C & 1,45 & 1,39 & 1,00 & TS \\
Net B/C & 2,46 & 2,12 & 3,41 & S \\
IRR (\%) & $18,66 \%$ & $16,85 \%$ & 2,34 & \multicolumn{1}{c}{$\mathrm{S}$} \\
PP (Thn) & 4,24 & 4,29 & 0,23 & TS \\
Penurunan Produksi $(25 \%)$ & & & \\
NPV (Rp) & 72.345 .512 & 11.570 .471 & 0,05 & TS \\
Gross B/C & 1,45 & 1,20 & 0,66 & TS \\
Net B/C & 2,46 & 1,22 & 2,35 & S \\
IRR (\%) & $18,66 \%$ & $10,93 \%$ & 1,83 & S \\
PP (Thn) & 4,24 & 4,28 & 0,03 & TS \\
\hline Keterangan : & & & &
\end{tabular}

LK : Laju Kepekaan

TS : Tidak sensitif (kurang dari 1)

S : Sensitif (lebih dari 1)

Hasil analisis sensitivitas pada Tabel 4, menunjukkan bahwa analisis sensitivitas usahatani pala dengan asumsi kenaikan biaya produksi sebesar $4,45 \%$ sensitif terhadap perubahan . Hal tersebut ditunjukkan dengan nilai laju kepekaan $\mathrm{Net} B / C$ dan IRR lebih besar dari satu (>1) yakni 3,41 dan 2,34.

Asumsi penurunan produksi pala sebesar $25 \%$ hanya sensitive terhadap perubahan nilai $\mathrm{Net} \mathrm{B} / \mathrm{C}$ dan IRR dengan nilai laju kepekaan 2,35 dan 1,83. Nilai laju kepekaan IRR dan Net B/C lebih besar dari satu (>1), sehingga sensitif terhadap perubahan yang terjadi. Jika dibandingkan dengan tanaman kakao pada penelitian kelayakan ekonomi dan pemasaran kakao yang dilakukan oleh Rizal, Hasyim, dan Situmorang (2017) bahwa asumsi penurunan produksi pada analisis sensitivitas kakao menunjukkan laju kepekaan yang sensitive terhadap Net $B / C$ dan IRR dengan nilai laju kepekaan lebih besar dari 1 .

\section{Prospek Pengembangan Pala}

Prospek usahatani pala di Provins Lampung yang dilihat dari produksi pala dan ekspor biji pala Provinsi Lampung di masa mendatang dapat dilihat dari analisis peramalan (forcasting) menggunakan model ARIMA. Data yang digunakan adalah data sekunder untuk produksi pala di Provinsi Lampung tahun 2006 hingga tahun 2014. Data volume ekspor biji pala di Provinsi Lampung yakni tahun 2011 hingga tahun 2017. Peramalan (forcasting) yang dilakukan pada produksi pala dan ekspor biji pala di Provinsi Lampung dilakukan melalui tiga tahap. 
Pada tahap awal uji stasioneritas data, ke dua data tersebut belum stasioner. Oleh sebab itu, perlu dilakukan proses differencing. Pada $1^{\text {st }}$ differencing data produksi pala dan ekspor biji pala di Provinsi Lampung menunjukkan bahwa ke dua data telah stasioner. Data yang telah stasioner yang akan digunakan untuk melakukan peramalan (forcasting).

Tahap ke dua yakni melakukan penaksiran parameter (estimasi) dengan memasukkan berbagai model ARIMA yang terdiri dari parameter $\mathrm{p}, \mathrm{d}$, dan $\mathrm{q}$. Ordo $\mathrm{p}$ menunjukkan derajat autoregressive (AR), ordo d adalah tingkat differencing, dan ordo q menunjukkan derajat moving average (MA), sehingga model dapat ditulis (p,d,q). Hasil identifikasi awal menunjukkan data historis produksi pala dan ekspor biji pala di Provinsi Lampung stasioner pada $1^{\text {st }}$ differencing. Oleh sebab itu, ordo d pada model ARIMA untuk kedua data yakni 1. Penaksiran parameter (estimasi) menghasilkan masing-masing empat kemungkinan model terbaik dengan persamaannya yang akan dibandingkan.

Kriteria pemilihan model terbaik yakni dengan melihat nilai Schwars Criterion yang kecil, nilai Akaike Info Criterion (AIC) yang kecil, nilai Sum Squared Resid (SSE) dan nilai Adjusted $R$ Squared yang besar. Penaksiran parameter (estimasi) model ARIMA untuk produksi pala di Provinsi Lampung menghasilkan model terbaik yakni $(1,1,5)$ dengan persamaan $\mathrm{Yt}=1,153+$ $0,380_{\text {ut }-1}-0,999_{\text {ut }-5}$. Nilai 1,153 menunjukkan koefisien model dengan nilai probabilitas sebesar 0,0000; nilai 0,380 menunjukkan nilai pada AR (1) dengan nilai probabilitas sebesar 0,0001; dan nilai 0,999 menunjukkan nilai pada MA (5) dengan probabilitas sebesar 0,0000 . Oleh sebab itu, model ARIMA $(1,1,5)$ merupakan model terbaik dengan nilai signifikan pada model yaitu sebesar $99 \%$.

Penaksiran parameter (estimasi) model ARIMA juga dilakukan untuk volume ekspor biji pala di Provinsi Lampung yang menghasilkan model terbaik yaitu ARIMA $(0,1,4)$ dengan persamaannya $\mathrm{Yt}=8,834-0,999$ ut- $4+$ et. Nilai 8,834 menunjukkan koefisien model dengan nilai probabilitas sebesar 0,000 ; dan nilai 0,999 menunjukkan nilai pada MA (4) dengan probabilitas sebesar 0,000 . Oleh sebab itu, model ARIMA $(0,1,4)$ merupakan model terbaik dengan nilai signifikan pada model tersebut yakni sebesar $99 \%$.
Tabel 5. Hasil peramalan produksi pala dan ekspor biji pala di Provinsi Lampung

\begin{tabular}{ccccc}
\hline & \multicolumn{4}{c}{ Hasil Peramalan (ton) } \\
\cline { 2 - 5 } Tahun & $\begin{array}{c}\text { Produksi } \\
\text { pala }\end{array}$ & $\begin{array}{c}\text { Laju } \\
\text { pertumb } \\
(\%)\end{array}$ & $\begin{array}{r}\text { Ekspor } \\
\text { biji pala }\end{array}$ & $\begin{array}{c}\text { Laju } \\
\text { pertumb } \\
(\%)\end{array}$ \\
\hline 2015 & 75,99 & - & - & - \\
2016 & 87,28 & 12,94 & - & - \\
2017 & 98,72 & 11,59 & - & - \\
2018 & 110,21 & 10,43 & 36,94 & - \\
2019 & 121,73 & 9,46 & 45,77 & 23,9 \\
2020 & 133,26 & 8,65 & 54,6 & 19,3 \\
2021 & 144,79 & 7,96 & 63,44 & 16,2 \\
2022 & 156,32 & 7,38 & 72,27 & 13,9 \\
2023 & 167,85 & 6,87 & 81,11 & 12,2 \\
2024 & 179,38 & 6,43 & 89,94 & 10,9 \\
2025 & - & - & 98,77 & 9,80 \\
2026 & - & - & 107,61 & 9,00 \\
2027 & - & - & 116,44 & 8,20 \\
\hline
\end{tabular}

Tahap ke tiga yakni tahap peramalan (forcasting) dengan hasil peramalan yang dapat dilihat pada Tabel 5. Hasil peramalan yang diperoleh menunjukkan bahwa produksi pala 10 tahun mendatang dengan rata-rata peningkatan produksi pala di Provinsi Lampung sebesar $11 \%$ per tahunnya. Hasil peramalan produksi pala sejalan dengan rencana strategis kebijakan pemerintah mengenai peningkatan produksi tanaman rempahrempah pada tahun 2015 hingga tahun 2019, salah satunya adalah tanaman pala. Konsumsi pala diperkirakan akan meningkat pada tahun 2016 hingga tahun 2020 dengan rata-rata pertumbuhan sebesar $0,85 \%$ per tahun dan total konsumsi sebesar 576 ton (Kementerian Pertanian 2016).

Peningkatan produksi pala yang positif dapat mendorong nilai perekonomian Provinsi Lampung, salah satunya dengan kegiatan ekspor biji pala. Tanaman pala yang hanya tumbuh di iklim tropis menjadi alasan negara lain mengandalkan impor pala dari negara iklim tropis terutama Indonesia. Hal inilah yang mendorong beberapa negara seperti Rusia, United States, dan Jerman melakukan impor dari Provinsi Lampung. Hasil penelitian Hafif, Mawardi, dan Utomo (2017) mengenai analisis karakteristik lahan dan mutu biji pala menyatakan bahwa biji pala di Provinsi Lampung telah memenuhi Standar Nasional Indonesia (SNI) yaitu 01-0006-93 dan standar BJ dari FAO yang telah memenuhi standar transportasi pasar pala global.

Hasil peramalan ekspor biji pala di Provinsi Lampung 10 tahun mendatang mengalami peningkatan di setiap tahunnya. Akan tetapi, laju pertumbuhan ekspor biji pala cenderung menunjukkan penurunan volume ekspor biji pala. 
Hal tersebut dikarenakan pertumbuhan volume ekspor biji pala yang cenderung konstan. Provinsi Lampung telah mengekspor biji pala dari tahun 2011 hingga tahun 2017 ke beberapa negara di Eropa dan Amerika. Jika dilihat dari segi Pangsa Produsen (Producen Share), Provinsi Lampung memiliki nilai Producen Share pada tahun 2017 sebesar $37,43 \%$ terhadap volume ekspor biji pala. Producen Share yang ditunjukkan tersebut mengindikasikan bahwa ekpor biji pala di Provinsi Lampung menghasilkan keuntungan, namun masih tergolong cukup rendah dilihat dengan nilai Producen Share kurang dari 50\%. Hal ini disebabkan harga biji pala yang diterima petani pada tahun 2017 tergolong rendah.

Perdagangan biji pala di Provinsi Lampung termasuk dalam kategori tidak terdapat integrasi dikarenakan ekspor biji pala Provinsi Lampung memiliki nilai Intra-Industry Trade (IIT) sebesar 0,00 . Nilai tersebut menunjukkan bahwa hanya terjadi satu aliran perdagangan (one way trade) yaitu Provinsi Lampung hanya melakukan ekspor ke beberapa negara di Eropa dan Amerika serta Provinsi Lampung tidak melakukan impor pala dari negara tersebut. Hubungan satu arah ini menunjukkan bahwa negara importir memiliki kebutuhan impor yang cukup tinggi terhadap biji pala Provinsi Lampung, sehingga Provinsi Lampung dapat meningkatkan produksi biji pala untuk memenuhi kebutuhan ekspor biji pala. Hal ini sejalan dengan penelitian Raharti (2013) yang menyatakan bahwa hanya terjadi satu aliran perdagangan pala yang dilakukan Indonesia ke negara Jerman dan Belgia.

Merujuk dari hasil peramalan (forcasting) pada Tabel 5, produksi pala mengalami peningkatan berbanding lurus dengan volume ekspor biji pala dalam kurun waktu 10 tahun mendatang. Perlunya perhatian pemerintah terhadap peningkatan mutu hasil pengolahan pala yang dilakukan oleh petani. Peningkatan mutu hasil pengolahan pala dimasudkan agar komoditi pala Lampung memiliki nilai tambah lebih disertai dengan peningkatan produksi pala, sehingga dapat meningkatkan ekspor pala di pasar internasional.

\section{KESIMPULAN}

Usahatani pala di Provinsi Lampung secara finansial layak untuk dikembangkan dan prospek pengembangan usahatani pala di Provinsi Lampung dilihat dari produksi pala dan ekspor biji pala memiliki potensi yang baik untuk dikembangkan di masa mendatang.

\section{DAFTAR PUSTAKA}

Astanu DA, Ismono RH, dan Rosanti N. 2013. Analisis kelayakan finansial budidaya intensif tanaman pala di Kecamatan Gisting Kabupaten Tanggamus. JIIA, 1 (3) : 218-225 http://jurnal.fp.unila.ac.id/index.php/JIA/arti cle/view/576/538. [18 September 2017].

Borolla JD. 2014. Analisis kelayakan bisnis komoditi unggulan pala di Wilayah Kapet Seram. Jurnal Benchmark, 3 (1) : 119-127. https://www.academia.edu/10251713/19_ben chmark_Volume_3. [17 November 2018].

BPS [Badan Pusat Statistik]. 2014. Statistik Perdagangan Luar Negeri Indonesia : Ekspor Jilid II. BPS. Jakarta.

Dinas Perkebunan Provinsi Lampung. 2015. Penghasil Pala di Provinsi Lampung. Dinas Perkebunan Provinsi Lampung. Bandar Lampung.

Dinas Perkebunan Provinsi Lampung. 2016. Luas Areal Lahan Pala di Provinsi Lampung. Dinas Perkebunan Provinsi Lampung. Bandar Lampung.

Dinas Perdagangan Provinsi Lampung. 2017. Volume Ekspor Biji Pala Lampung dan Negara Tujuan Ekspor. Dinas Perdagangan Provinsi Lampung. Bandar Lampung.

Gittinger J. 1993. Analisis Ekonomi Proyek Proyek Pertanian. PT Rineka Cipta. Jakarta.

Hafif R, Mawardi R, dan Utomo JS. 2017. Analisis karakteristik lahan dan mutu biji pala daerah Lampung. Jurnal Littri, 23 (2) : 63-71. http://ejurnal/litbang.pertanian.go.id/ indexphp/jptip/article/view/7202. November 2018].

Hatta S. 1993. Budidaya Pala Komoditas Ekspor. Debut Press. Yogyakarta.

Kadariah. 2001. Evaluasi Proyek Analisa Ekonomi. Lembaga Penerbit Fakultas Ekonomi Universitas Indonesia. Jakarta.

Kementerian Pertanian. 2016. Rencana Strategis Perkebunan Indonesia. Pusat Data dan Informasi Pertanian Sekretariat Jenderal Kementerian Pertanian. Jakarta.

Raharti PR. 2013. Analisis Daya Saing dan Faktor-Faktor yang Mempengaruhi Aliran Ekspor Pala Indonesia. Skripsi. Institut Pertanian Bogor. Bogor.

Rizal RK, Hasyim AI, dan Situmorang S. 2017. Kelayakan ekonomi dan pemasaran kakao di Kabupaten Lampung Selatan. JIIA, 5(4): 384-391. http://jurnal.fp.unila.ac.id/index.pp/ JIA/article/view/1747/1550. [15 Oktober 2018]. 